\title{
Against Leadership Odds: A Township School Principal's Crusade for Social Justice
}

\author{
Patrick Mafora
}

\author{
University of South Africa \\ Department of Educational Leadership and Management \\ Email:pmafora@unisa.ac.za
}

\section{Doi: 10.5901/mjss.2013.v4n4p239}

\begin{abstract}
The aim of this qualitative case-study was to explore one Soweto secondary school principal's social justice leadership strategies which account for the school being perceived as democratically transformed and socially just. This was a follow-up to two bigger qualitative studies of five and three schools, respectively. Data were collected through a series of in-depth semistructured interviews and observations. Data analysis followed Teschs steps for open coding. Findings suggest that the principal's personal values and commitment to social justice principles account for his resilience in the face of resistance and systemic barriers. Social justice leadership strategies employed by the principal and the barriers he encounters are outlined. The paper concludes that, notwithstanding barriers, the negative effect of the marginalising conditions that are prevalent in impoverished communities and schools can be minimised through the principal's social justice leadership.
\end{abstract}

Keywords: equity; leadership; marginalisation; secondary school; Soweto

\section{Introduction}

Educational reform in developing countries is one of the means of bringing socio-economic change to individuals and the broader society (Swanepoel, 2008; Parameswaran \& Kader, 2009; Pandey \& Vedak, 2010). In South Africa, transforming the education system was meant to help overcome the devastation of apartheid and provide a system that builds democracy, human dignity, equality, redress, and social justice (Department of Education, 2001; Motala, 2001). Thus, among the key objectives emphasised in the legislative framework for the new education system are equity, social justice, and democratic transformation (Ministry of Education, 2000; Pendlebury \& Enslin, 2004).

School principals are responsible for giving effect to these policy prescripts and reforms in schools. However, because of heavy workloads and ever changing demands on the role of school principals, they are unable to attend equally to all the tasks flowing from policy imperatives. In the main, principals are under pressure to implement policies that relate to student achievement and standards and in the process they neglect social justice work (Stevenson, 2007; Theoharis, 2007; 2009), and building respect for diversity (Alsbury \& Whitaker, 2006). Some principals view themselves as managers not leaders who must address issues of social justice and marginalisation (Marshall and Ward, 2004). This is a plausible explanation for the prevalence of social injustice in some schools in South Africa (Pendelbury \& Enslin, 2004), in spite of a policy framework that promotes equity and social justice. Teachers, students and parents face marginalisation, discrimination, and inequitable treatment in schools (Pendlebury \& Enslin, 2004; Brown, 2006; Mabovula, 2009; Mafora, 2012).

Given their policy implementation role and the fact that social justice is a virtuous policy proposition, it is a reasonable expectation that principals should promote and exemplify social justice tenets in their leadership practices. A commonly held view supporting this position is that social justice is inextricably linked with educational leadership (Bogotch, 2002; Johansson Fua, 2007; Normore \& Jean-Marie, 2008). It was thus considered pertinent to examine the manifestation of social justice leadership in township secondary schools.

\subsection{Study context and background}

School leadership literature suggests that both leadership (Leithwood and Riehl, 2003), and social justice (Johansson Fua, 2007) are context-specific. In this regard, Alsbury and Whitaker (2006) opine that student background factors like socio-economic status, ethnicity and culture impact on how leaders discharge their responsibilities. A related view is that 
urban principals often have to address issues unrelated to education but which may compromise the instructional focus (Peebles and Hopstone, 2007). Given the centrality of context to social justice leadership, it is significant to precede a discussion of the principal's social justice leadership practices with an outline of the context of this study.

This study is a sequel to two qualitative case studies that examined stakeholders' perceptions regarding the leadership and management of secondary schools in Soweto. The first study focused on shared decision-making among School Governing Body (SGB) members in five schools. The second study examined the manifestation of transformative leadership for social justice in School Management Teams (SMTs) of three schools. The principal who is the subject of this study participated in the two studies. In keeping with the undertaking to maintain confidentiality and anonymity, the pseudonyms "Serenity Secondary School" and "John" will be used to refer to the school and the principal, respectively.

Serenity secondary school is public, co-educational, and admits students from class grades eight to twelve. All students and teachers at this school are Black Africans. It is located in Soweto Township, a part of Johannesburg WestD12 Education district. Most families in the area have working class, low socio-economic backgrounds. The informal settlement which is one of the feeder areas for Serenity secondary school is one of the seven most deprived wards, out of 109 , in the City of Johannesburg and has the worst levels of food insecurity, the highest recipients of child support grants and, female headed families (De Wet, Patel, Korth \& Forrester, 2008). In a recent study of Soweto households Gray et al. (2006) found, among others that, $11 \%$ of children had lost a parent; $44 \%$ of households had at least one sick adult and could not pay school fees for their children or assist them with homework.

Spreen and Vally (2006) maintain that poverty tends to bar students in townships and informal settlements from accessing and receiving quality education. Inevitably, these students drop out of school because of exposure to sexual violence, harassment or rape, and physical violence. Student access to these schools is also restricted by inadequate transport, effects of HIVIAIDS, and discriminatory practices against linguistic minorities and immigrants (Pendlebury \& Enslin, 2004). The majority of schools in Soweto are considered dysfunctional and characterised by unacceptable conduct like: corporal punishment for students, low student achievement, poor discipline from students and teachers, physical assault on students and teachers and, drug and alcohol abuse (Mokonyane, 2011).

Conceived against this background, the aim of this study was to explore the principal's leadership practices which the majority of surveyed teachers, students and parents in earlier studies perceived as socially just, and to which they attributed their perceived democratic transformation of the school. This aim was refined into these research questions:

- What is the principal's conception of social justice leadership for schools?

- Which leadership strategies does the principal employ to enhance social justice?

- What are the barriers faced by the principal when exercising social justice leadership?

\section{Conceptual framework on social justice leadership in schools}

The body of literature on social justice points to a myriad of meanings ascribed to this concept (Bogotch, 2002; Goldfarb \& Grinberg, 2002; Rizvi, 1998; Chubbuck, 2010). It also identifies a movement in the social justice discourse that expressly argues against a universal definition of the concept (Bogotch, 2002; Shoho, Merchant \& Lugg, 2005; Theoharis \& Futtura, 2008). Without discounting these claims, this study is guided by what Hytten and Bettez (2011) call the practical strand of social justice. This strand does not seek to provide a theoretical or philosophical definition of social justice, but describes and offers criteria for a socially just practice in education. On the basis of these descriptors and criteria, a distinction is made between practices of leaders who are social justice agents and those who are not, and between socially just and unjust schools. This framework is relevant to the research questions of this study in that it provides specific examples of what works in challenging inequities and creating equality of opportunities (Hytten \& Bettez, 2011).

This paper adopts a simplistic view of social justice as the opposite of injustice (Lee \& McKerrow, 2005; Chubbuck, 2010). Chiu and Walker (2007) maintain that in schools social justice is about working to reduce student disadvantage at the classroom, organisation, family, community, and the broader society. This coheres with the view that leaders for social justice seek to eliminate societal inequities that are manifest in their school communities (Cambron-McCabe \& McCarthy, 2005; Larson \& Murtadha, 2002). The focus of social justice leadership efforts is thus not restricted to marginalising conditions within schools. Carlise, Jackson and George (2006) maintain that socially just teachers must become activists seeking to address inequities wherever societal policies and practices oppress students and limit the quality of their lives and learning opportunities, [emphasis mine]. Emergent common emphases from different conceptualisations of social justice leadership in schools are that it involves: 
- $\quad$ questioning institutional culture and assumptions underlying school policies and practices (Bogotch, 2000; Cambron-McCabe \& McCarthy, 2005);

- altering institutionalised inequalities, discrimination and injustices (Goldfarb \& Grinberg, 2000; Chiu \& Walker, 2007; Place et al., 2010);

- social activism with a focus on equity within and beyond school borders (Larson \& Murtadha, 2002; Brown, 2006; McKenzie et al., 2008; Chubbuck, 2010);

- creating a climate that fosters a sense of belonging to all community members (Theoharis, 2010);

- $\quad$ being open, sensitive and authentic in the treatment of teachers (Hoy \& Tarter, 2004);

- creating learning opportunities and maintaining high expectations for all students (Brown, 2006; Riehl, 2000; Scheurich \& Skrla, 2003);

- $\quad$ raising the achievement of all students (Shields, 2004; Theoharis, 2007; Place et al., 2010);

- $\quad$ the principal's exemplary conduct (Theoharis, 2007, 2010);

- $\quad$ preparing students to live as critical citizens in society (Shields, 2004; Carlise et al., 2006; Chubbuck, 2010); and

- $\quad$ encouraging critical reflection on, and commitment to social justice among teachers (Riehl, 2000; CambronMcCabe \& McCarthy, 2005; Landorf \& Nevin, 2007).

The range of leadership practices suggested in these conceptions of social justice leadership is broad, covering students, teachers, policies and, life within and beyond the school. This depth of responsibilities lends credence to the view that, given their pivotal positions in schools, it is school leaders who can alter the status quo (Brown, 2006; Chiu \& Walker, 2007). Schools are, however, generally viewed as conservative and as likely to maintain, rather than question, the status quo (Apple, 1990; Freire, 1990). They are said to mirror the power relations that exist in the larger society (Applebaum, 2003), and to be characterised by cultural politics that reproduce and perpetuate some inequities, and legitimate some cultures while others are marginalised (Larson \& Murtadha, 2002; Quartz et al., in Shields, 2010). Without the active intervention of a leader committed to social justice, such inequities and marginalisations are unlikely to be eradicated.

Schools which are not transformed into just entities expose members of the school community to inequities and hurtful experiences of injustice (Aydin \& Karaman-Kepenekci, 2007). The schools are characterised by racist words, hate speech and, social oppression which restricts freedom and inflicts psychological harm (Applebaum, 2003). Perceptions of injustice and inequities in these schools engender resentment, student low self-esteem, discipline problems and, teacher bias (Brown, 2006). They also encourage the school's authority to be undermined (Heinzel et al. in Chiu \& Walker, 2007). Parameswaran and Kader (2009) contend that marginalising experiences in schools amount to denied access and inhibited future prospects.

A socially just school, on the other hand, promotes inclusion and equity, holds high expectation for all students, develops reciprocal community relationships, and has direct social justice education and intervention (Carlise et al., 2006). Such schools become better educational environments with raised student achievement, improved structures, enhanced staff capacity and strengthened school culture and community (Theoharis, 2007). It must be noted, however, that a perfect socially just school or social justice leader does not exist (McKenzie et al., 2008). Leaders may only be strong in some aspects of social justice and not in others. Literature also suggests that in their quest to create socially just schools, educational leaders face a myriad of challenges that militate against their effectiveness (Rapp, 2002; Brown, 2004; Cambron-McCabe \& McCarthy, 2005; Lugg \& Shoho, 2006; Aydin \& Karaman-Kepenekci, 2007; Theoharis, 2007, 2010).

\section{Methodology}

The aim of this study was to explore the selected principal's social justice leadership practices. An exploratory, qualitative study was considered appropriate for examining this phenomenon from the participant's own perspective (McMillan \& Schumacher, 2006).

\subsection{The respondent}

The principal who is the unit of analysis in this study was purposively selected. As a participant in two earlier studies on shared decision-making and on transformative leadership for social justice, he described his role as "creating and sustaining a democratic culture in the school". Unlike the other four principals who participated in those studies, he was 
perceived as committed to democratic transformation and social justice by the majority of surveyed teachers, students and parents in his school. John is in his early 50 s with a teaching experience that spans over 25years. He has a teacher's professional certificate and a Higher Certificate in Educational Leadership and Management. He has occupied various leadership positions in primary schools. At the time of this study he was into the third year of principalship at Serenity secondary school.

\subsection{Data collection}

Data were collected through direct observations and in-depth semi-structured interviews. Interviews were considered more appropriate for uncovering the new insight which the study sought as they are generally more acceptable than questionnaires to managers who are passionate about a topic that relates to their work (Saunders, Lewis \& Thornhill, 2000). Three one-to-one interview sessions, of about one hour each, were held on different visits to the school. These visits were also used as opportunities for observations. Only one half-school-day was devoted solely to observations. The observation checklist and interview questions were based on the broad themes from the literature on social justice. Direct observations focused on the interactions among members of the school community. The interviews were audio recorded and transcribed verbatim.

\subsection{Data analysis}

Data analysis was iterative and continuous, following Tesch's method of open coding (Creswell, 2007). Emergent categories were named using actual terms used by the respondent (Saunders et al., 2000). These categories were subsequently integrated into the literature to contextualise the data in the discussion of findings. Trustworthiness was enhanced through triangulation and member checking with the principal on each subsequent visit and after the final data analysis.

\subsection{Ethical considerations}

In line with the applicable code of research ethics (Saunders et al. 2000), permission for the study was obtained from the Gauteng Provincial Department of Education. The principal gave informed consent to participate in the study and have the interviews recorded. Data collection was not intrusive, inopportune, or stressful and I undertook to respect the participant's right not to answer questions or to withdraw from the study if deemed necessary. Pseudonyms are used to maintain anonymity.

\section{Findings and discussion}

The findings presented below are structured to answer each research question. For each question, pertinent answers are subsumed under the three broad themes which were named using terms used by the respondent (Saunders et al. 2000) in his narrative. These themes, which are discussed individually in detail below, are: personal beliefs about social justice, making a socially just difference and, challenges of becoming a just leader.

\subsection{Personal beliefs about social justice}

Unlike principals who get involved in social justice without knowing that they are involved (Normore \& Jean-Marie, 2008), John described his role in terms that suggest he is aware of and committed to being a social justice agent. John's response to the question, what do you understand by social justice leadership in schools? suggests that he has an insightful understanding of both teaching for social justice and social justice leadership. In his response, part of which was unsolicited, he argued that social justice leadership was a condition for socially just teaching in schools. His explication of teaching for social justice emphasised how content, teaching methods, the teaching process, relationships, and the teacher's value system should enhance learning by challenging inequities associated with schools and their communities. One comment in this regard, which echoed the view that social justice is the opposite of injustice (Lee \& McKerrow, 2005; Chubbuck, 2010) was: 
students' background cannot be just teaching. Teaching the right thing in a wrong way, with a wrong attitude makes teaching wrong...

It is noteworthy that John does not view social justice leadership as an abstraction, but a practice in which he as a principal is immersed and must use to leverage change regarding unjust practices. He remarked:

As a principal I cannot expect the Department of Social Welfare to intervene in my school and provide lunch to learners who come to school hungry or do not have proper school uniform. I cannot say the Department of Education must stop teachers from using corporal punishment or stop them from abusing learners? No, these are problems that I should deal with. Social justice leadership means that I must ensure that nothing makes being at school and learning unpleasant.

The comment below indicates that John shares the view that social justice leadership efforts should be extended to, and seek to change, conditions beyond the school (Larson \& Murtadha, 2002; Brown, 2006; Chubbuck, 2010):

\begin{abstract}
Parents come to school all the time regarding problems they have with these learners at home. It can be anything from relationships, money, homework, you name it. We cannot chase parents away and say it is a problem for the family because if we do not assist then that problem will become our problem when it affects learning.
\end{abstract}

His understanding of this practice also coheres with Furman and Shields' (2003) contention that members of a given community base their views of social justice on their present circumstances, their historical context, and what they view as the moral purpose of their organisation.

He shares the view that social justice leadership is a values-based practice (Furman \& Shields, 2003; Normore \& Jean-Marie, 2006; Stevenson, 2007). In terms of this view social justice leaders should not just implement policies passively or uncritically. Rather, their decisions should reflect a careful consideration of moral or ethical issues as well as personal and institutional values (Starratt, 2004; Stevenson, 2007). His informative comment in this regard was:

A just principal should be aware of the negative consequences of some policies and implement them carefully, if one cannot ignore them completely. School policies and leaders who promote inequality and unfairness must not be supported...

\title{
4.2 Making a socially just difference
}

When asked to describe his strategies for advancing social justice, John pointed out that he used a repertoire of attitudes and practices that are meant "to make a difference in the lives of the school community". He argued that even in the absence of injustice, he would still adopt these practices and make a difference in other ways. This, however, does not relegate him to the category of principals who do not have social justice issues to deal with but a concern for students in general (Place et al., 2010). John's practices are relevant for purposes of this study as they provide answers to the second research question: which leadership strategies does the principal use to enhance social justice?

For ease of discussion, John's strategies are discussed next in relation to the broad areas in which he seeks to make a difference, albeit he maintained that they are not situation or problem-specific. The areas which are the foci of the envisaged difference are: students, teachers and the curriculum and, school climate and the community.

\subsubsection{Making a difference to students}

According to John he is duty-bound to provide a fruitful and fulfilling learning experience for students. He said he does not want his students to experience discrimination, systemic abuse and deprivation which he was exposed to as a student under the apartheid education system.

$\mathrm{He}$ criticises the common practice, which is encouraged by the district office, of raising student achievement by tampering with their exam scores outside of the moderation process. He has resisted directives from the district office to do so. To raise student achievement, he initiated additional time for studies through Saturday morning classes and a winter vacation school. These classes are regular, inclusive and non-remedial. He maintains that giving underachieving students their own special classes stigmatises them as permanently deficient. Although this strategy coheres with Stevenson's (2007) suggestion, it is not completely appropriate for Serenity secondary school which practices 
achievement-based tracking. It amounts to an attempt to perfect, rather than discontinue tracking. His remark regarding how the school deals with students whose personal circumstances affect their achievement was revealing:

\begin{abstract}
...they attend same classes with other learners with comparable ability [learning achievement]. It is a case of being more sensitive to their situation and accommodating them, like giving extensions for homework and project submission dates, making school facilities available for their use after school [hours], and prioritising them when learning-teaching materials are distributed. They get additional lessons only if they fall way behind... We arrange motivational talks to give learners hope that their challenges can be overcome.
\end{abstract}

Although the school is considerate to students with marginalising conditions, in line with the vision of equity of excellence (Shields, 2004), John maintained that the school does not have lower expectations regarding their achievement. Instead, the students are expressly told that it is because of high expectations that they were being privileged over others. Those with potential are usually identified and encouraged to enter local and national student competitions where knowledge, skill or competence, not background, are tested. This is meant to make them believe in themselves and that success is possible. Some trophies awarded for student achievement were displayed in the principal's office.

To entrench a culture of social justice and altruism, the student code of conduct treats failure to report abuse of power, harassment, discrimination or unfair treatment, even when not perpetrated against oneself, as misconduct. All reported cases are followed through.

\title{
4.2.2 Making a difference to teachers and the curriculum
}

John aimed at turning the school into "the best employment space where teachers feel valued and respected". On being appointed, he prioritised making the school decision-making structures more broad-based and inclusive. He wanted to enhance a sense of belonging and the need to serve among teachers. To this end, in addition to the SMT which comprises of the principal, deputy principals and heads of departments, he introduced a number of committees that decide on different issues that affect teachers, like finance and student discipline. Membership of these committees is decided by teachers themselves. To make teachers feel valued as persons, not just employees who must do their jobs, he discusses matters that affect individuals privately, not in open meetings. He said he seeks to understand possible reasons for the state of affairs before making judgements. He also tries to provide support in times of grief and celebrate individual teachers' achievements with them, even when these are not work related. This reflects the open, sensitive and authentic treatment of teachers expected from social justice leaders (Hoy \& Tarter, 2004).

John maintained that he is guided by fairness and equity considerations when making decisions that involve the distribution of resources, or decisions which affect the interests and privileges of teachers. He involves the two deputy principals or a chairperson of the relevant committee when handling matters like teacher discipline, work allocation, provision of learning teaching-materials, leave and, appraisal. To assure teachers that the decisions that are made are not personal, he provides underlying reasons and remains open to discuss their concerns.

In line with the view that professional development is a condition for improving teaching (Elmore, 2002) and that student learning depends on quality teaching (Haycock, 2001) all teachers are encouraged to attend professional development workshops related to their subject fields. John facilitates attendance by making information available to all teachers and processing related documentation timeously. Several notices attesting to this were pasted on the bulletin board at the reception. To make up for lack of staff development on social justice issues, John holds informal information-sharing sessions with individual teachers. These are for mutual-reflection on social justice issues that relate to them or students. In such sessions he does not seek to talk-down to teachers or pretend to be all-knowing, but becomes their equal.

\subsubsection{Making a difference to the community and changing school culture}

John's concern was that his school was getting more and more alienated from the community. Teachers' interaction with community members was restricted to school matters within the school premises. None of the teachers resided in that community or had children attending school there. His goal was to establish positive school-community relations to foster a sense of connectedness and mutual service on which success for an organisation that pursues social justice depends (Goldfarb \& Grinberg, 2002). 
He has established a community outreach initiative that, "seeks to take the school to the community and reclaim the position of the community in the school". While it is standard practice for parents to collect their children's report cards at the school at the end of a term, some parents have report cards delivered at their homes by teachers. This is when parents cannot come to the school for some reason, or the school has some concern regarding the student, like achievement, attendance, discipline or general well-being. Some visits are just for touching base and finding out how parents cope with a given challenge that is known to the school. Parents are also encouraged to visit the school whenever they can and to provide voluntary services. Maintenance jobs and once-off tasks that are paid for by the school are reserved for unemployed parents. Before the school was classified as a no-fee school, unemployed parents were allowed to render service to the school in lieu of school fees. Whenever there is a pressing need, like bereavement in a poor family, the school makes facilities available but waives the fee that is normally charged. Students from such families are on the school's free lunch programme whose meals are cooked by parents. They are also exempted from paying when fund-raising initiatives require direct payment from parents.

When there are festivities to celebrate some event, like the World Aids Day, the school invites community members, without regard for their class or status. This is attested by photos of parents mingling with teachers and students on the reception bulletin board. A student was seen helping an elderly parent to ascend a few steps in front of the administrative building. Admin support staff that stopped to greet parents at the reception and enquired if they had been attended to, were a common sight.

John remarked that his strategies would in themselves not work if the school community did not believe in him as a person before respecting him as a professional teacher and principal. He said this awareness motivates him to seek to be exemplary at all times. He believes that he commands respect because of his humility, respect for others, empathy and, decisiveness.

It would not be far-fetched to conclude that these strategies are an adequate base to help enhance social justice in a school as they reflect the essence of social justice leadership outlined in the foregoing conceptual framework. Specifically, the strategies cohere with Lee and McKerrow's (2005: 1) description of social justice leaders as:

striving for critique rather than conformity, compassion rather than bureaucracy, polyphony rather than domination, action rather than silencing, inclusion rather than exclusion, liberation rather than domination, action for change rather than inaction that preserves inequity.

\subsection{Challenges of becoming a just leader}

Data suggest that challenges faced by John are consistent with those experienced by principals who attempted social justice work in different contexts (Theoharis, 2007, 2009, 2010; Normore \& Jean-Marie, 2007; Place et al., 2010). John also encountered challenges within the school, in the community, from the district office and in his own practices. His body language when outlining these challenges: shrugging shoulders, raising arms, and gesticulating disapproval, with left-right tilts of the head, was suggestive of a sense of frustration and despair.

He identified weaknesses in the social justice policy framework as the major barrier to his social justice work. He maintained that social justice work is unenforceable. Because it is not mentioned as a requirement in teachers' conditions of service, non-compliance was not a punishable misconduct. Teachers then tend to view it as a voluntary inconvenience. Consistent with other findings (Aydin \& Karaman-Kepenekci, 2007; Normore \& Jean-Marie, Theoharis, 2007) some teachers reportedly, hinder social justice work through their beliefs, attitudes and practices that promote inequities and marginalisation. John's indicting remark, in this regard, was:

We cannot say we uphold human rights and respect human dignity when some of us still want to use corporal punishment and make fun of learners' personal circumstances. What message do we send when some teachers do not want to teach some classes because learners there are repeaters, or are ill-disciplined, or whatever? It surely says some learners are not important....

John lamented what he called the abdication of the district officials regarding social justice. He said they were more interested in enforcing compliance with learner achievement regulations than in helping schools to address the very factors that may affect student achievement. While none of the staff development programmes that district officials offered had a bearing on social justice issues, limited financial resources made it difficult for him to arrange relevant training for his school.

According to John the expectations and behaviour of some marginalised individuals tends to inhibit social justice work, "once disadvantage and injustices are deeply ingrained in their psyche and are not questioned". Citing examples of 
parents who insist that their children should receive corporal punishment, or those who want to de-register their pregnant children from school, he pointed out that these expectations strain the school-community relations. When he takes a tough-love stance and decides against their wishes, these parents isolate themselves and shun school activities.

An interesting finding was that Principal John considers himself to be "one of the factors that stall social justice work" in his school. Echoing other findings (Rapp, 2002; Brown, 2004; Cambron-McCabe \& McCarthy, 2005), he attributed "[his] limited success" to receiving no training for social justice work as a teacher and since becoming a principal. He opined that it was possibly because of lack of training that his social justice leadership elicits resistance from some teachers who view it as overbearing.

\section{Conclusion}

The purpose of this paper was to explore one principal's social justice leadership practices in the context of a township secondary school. The principal's conception of social justice leadership turned out to be framed within, and as a means of addressing, the inequities and injustices manifest within this specific school and its wider community. He emphasised what social justice leaders should do, how and the purpose of social justice leadership in schools. Findings challenge the stereotypical notion that township schools are led by bureaucratic and undemocratic principals with a general disregard for social justice issues. Rather, the findings provide some grounds for optimism regarding social justice work in that, notwithstanding systemic barriers and challenges, there is a principal who is determined to make a difference to others and commit to formidable social justice work, instead of opting to be just a manager.

To entrench social justice leadership in schools it needs to be prioritised and formalised as one of the job requirements for principals. It may be infused into their Key Performance Areas (KPAs) and be part of their accountability measures. This, in turn, would make support for social justice work from the education district office mandatory. The Department of Basic Education should sensitise principals to social justice issues and expand their professional and knowledge base of relevant leadership practices through continuous professional development initiatives (Cambron-McCabe \& McCarthy, 2005; Karpinski \& Lugg, 2006).

Principals who show a commitment to social justice leadership should be incentivised through awards of some sort as it is done for general administration, sport and teaching. To sustain their resilience in social justice work, it can also be helpful if principals can form communities of reflective practice through which they can examine and critique their taken-for-granted values, beliefs and practices regarding socially just school leadership.

A longitudinal study which focuses on social justice practices of more principals from more diverse schools is recommended. It can help give a holistic and comparative picture of social justice leadership in schools and, help overcome associated shortcomings.

\section{References}

Apple, M. (1990). Ideology and Curriculum. London: Routledge and Kegan Paul.

Applebaum, B. (2003). Social justice, democratic education and the silencing of words that wound. Journal of Moral Education, 32(2), $151-162$.

Alsbury, T.L. \& Whitaker, K.S. (2006). Superintendent perspectives and practices of accountability, democratic voice and social justice. Journal of Educational Administration, 45(2), $154-174$.

Aydin, I., \& Karaman-Kapenecki, Y. (2008). Principals' opinions of organisational justice in elementary schools in Turkey. Journal of Educational Administration. 46(4), $497-513$.

Bogotch, I.E., (2002). Educational leadership and social justice: Practice into theory. Journal of School Leadership, 12(2), 138 - 156.

Brown, K. (2006). "New" educational injustices in the "new" South Africa. Journal of Educational Administration, 44(5), 509 - 519.

Brown, K. (2004). Leadership for social justice and equity: Weaving a transformative framework and pedagogy. Educational Administration Quarterly, 40(1), $79-110$.

Cambron-McCabe, N. \& McCarthy, M. (2005). Educating school leaders for social justice. Educational Policy, 19(1), 201-222.

Carlise L.R., Jackson, B.W., \& George, A. (2006). Principles of social justice education: The social leadership. In C. Marshall \& M. Olivia (Eds.), Leadership for social justice: Making revolutions in education (pp. 16 - 30). Boston: Pearson.

Chiu, M.M. \& Walker, A. (2007). Leadership for social justice in Hong Kong schools: Addressing mechanisms of inequality, Journal of Educational Administration, 45(6), $724-739$.

Chubbuck, S.M. (2010). Individual and structural orientation in socially just teaching: Conceptualization, implementation, and collaborative effort. Journal of Teacher Education, 61 (3), 197 - 210.

Cresswell, J.W. (2007). Qualitative inquiry and research design: choosing among five approaches. (2nd ed.). Thousand Oaks, CA: Sage.

Department of Education, (2001). Education change and transformation in South Africa: A review 1994 - 2001. South African Government: South Africa. 
De Wet, T., Patel, L., Korth, M., \& Forrester, C. (2008). Johannesburg Poverty and Livelihood Study. Johannesburg: CSDA Report.

Elmore, R.F. (2002). Bridging the gap between standards and achievement: The imperative for professional development in education. Washington, DC: Albert Shanker Institute.

Freire, P. (1990). Pedagogy of the Oppressed. New York: Continuum.

Furman, G.C., \& Shields, C.M. (2003). How can educational leaders promote and support social justice and democratic community in schools? Paper presented at the Annual Meeting of the American Educational Research Association, Chicago, 9 - 12 April.

Goldfarb, K. P., \& Grinberg, J. (2002). Leadership for social justice in education: Authentic participation in the case of a community centre in Caracas, Venezuela. Journal of School Leadership, 12, $157-173$.

Gray, G.E., van Niekerk, R., Struthers, H., Violari, A., Matison, N., Mclntyre, J., \& Naidoo, V. (2006). The effects of adult morbidity and mortality on household welfare and wellbeing of children of Soweto. Vulnerable Children and Youth Studies, 1(1), $15-28$.

Haycock, K. (2001). Closing the achievement gap. Educational Leadership, 58(6), 6 - 11.

Hoy, W.K., \& Tarter, C.J. (2004). Organisational justice in schools: No justice without trust. International Journal of Educational Management, 18(4), $250-259$.

Hytten, K., \& Bettez, S.C. (2011). Understanding education for social justice, Educational foundations, Winter-Spring: 7 - 24.

Johnson Fua, S. (2007). Looking towards the source - social justice and leadership conceptualisations from Tonga. Journal of Educational Administration, 45(6), $672-683$.

Karpinski, C.F., \& Lugg, C.A. (2006). Social justice and educational administration: mutually exclusive? Journal of Educational Administration, 44(3), $278-292$.

Landorf, H., \& Nevin, A. (2007). Inclusive global education for social justice. Journal of Educational Administration, 45(6), 711 - 723.

Larson, C., \& Murtadha, K. (2002). Leadership for social justice, in J. Murphy (Ed.), The Educational Leadership Challenge: Redefining Leadership for the $21^{\text {st }}$ Century, (pp.134 - 161). University of Chicago Press: Chicago, IL.

Lee, S.S. \& McKerrow, K. (2005). Advancing social justice: women's work. Advancing Women in Leadership, 19, 1-2.

Leithwood, K.A., \& Riehl, C. (2003). "What do we already know about successful school leadership? Paper presented at the Annual Meeting of the American Educational Research Association, Chicago, IL, 22 April.

Lugg, C.A., \& Shoho, A.R. (2006). Dare public school administrators build a new social order Social justice and the possibly perilous politics of educational leadership. Journal of Educational Administration, 44(3), 196 - 208.

Mabovula, N. (2009). Giving voice to the voiceless through deliberative democratic school governance. South African Journal of Education, 29, $219-233$.

Mafora, P. (2012). Shared decision-making in school governance: A case study of two Soweto secondary schools, International Journal of Learning, 18(6), $97-107$.

Marshall, C., \& Ward, M. (2004). "Yes, but..." Education leaders discuss social justice. Journal of School Leadership, 14, 530 - 563.

McKenzie, K.B., Christman, D.E., Hernandez, F., Fierro, E., Capper, C.A., Dantley, M., Gonzalez, M.L., Cambron-McCabe, N., \& Scheurich, J.J. (2008). From the field: A proposal for educating leaders for social justice, Educational Administration Quarterly, $44(1), 111-138$.

McMillan, J.H., \& Schumacher, S.S. (2006). Research in Education: Evidence-based inquiry (6th ed.). Boston: Pearson.

Ministry of Education, (2000). Education in an era: Challenges to equity, opportunities for diversity. Country paper (RSA) presented at the 14th Conference of Commonwealth Education Ministers, Halifax, Canada, 27 - 30 November 2000. Pretoria: Government Printers.

Mokonyane, N. (2011). Address by the Premier, at the Soweto Education Summit, Johannesburg, 09 April 2011. [Online] Available: http://www.polity.org.za/article/gp-mokonyane (March 3, 2012).

Motala, S. (2001). Quality and indicators of quality in South African education: A critical appraisal. International Journal of Educational Development, $21(1), 61-78$.

Normore, A.H., \& Jean-Marie, G. 2008. Female secondary school leaders: At the helm of social justice, democratic schooling and equity. Leadership and Organisational Development Journal, 29(2), $182-205$.

Pandey, N., \& Vedak, V. (2010). Structural transformation of Education for sustainable development. International Journal of Environment and Sustainable Development, 9(1,2,3), 3 - 15.

Parameswaran, G., \& Kader, T. (2009). Educational access and social justice: A global perspective: University Press of America.

Peebles, L.D., \& Hopstone, T. (2007). Transformative leadership for diverse learning communities: Redefining the role of professional learning communities in urban schools, In S. Donahoo \& R.C. Hunter (ed.) Teaching Leaders to Lead Teachers: Advances in Educational Administration, 10, $313-329$.

Pendlebury, S. \& Enslin, P. (2004). Social justice and inclusion in education and politics: The South African case. Journal of Education, $34,31-50$.

Place, A.W., Ballenger, T.A., Wasonga, T.A., Perival, J., \& Edmonds, C. (2010). Principals' perspectives of social justice in public schools. International Journal of Educational Management, 24(6), 531 - 543.

Rapp, D. (2002). Social justice and the importance of rebellious imaginations. Journal of School Leadership, 12(3), $226-245$.

Riehl, C.J. (2000). The principal's role in creating inclusive schools for diverse students: A review of normative, empirical, and critical literature on the practice of educational administration. Review of Educational Research, 70, 55-81.

Rizvi, F. (1998). Some thoughts on contemporary theories of social justice. In B. Antweh, S. Kemmis, \& P. Weeks (Eds.). Action research in practice: Partnerships for social justice in education. (pp. $47-56$ ). London, UK: Routledge.

Saunders, M., Lewis, P., \& Thornhill, A. (2000). Research for Business Students. (2nd ed.). Essex: Pearson Education Limited.

Scheurich, J.J., \& Skrla, L. (2003). Leadership for equity and excellence. Thousand Oaks, CA: Corwin Press. 
Shields, C.M. (2004). Dialogic leadership for social justice: Overcoming pathologies of silence. Educational Administration Quarterly, 40, $109-132$

Shields, C.M. (2010). Transformative leadership: Working for equity in diverse contexts. Educational Administration Quarterly, 46, 558 589

Shoho, A.R., Merchant, B.M., \& Lugg, C.A. (2005). Social justice: Seeking a common language. In F.W. English (Ed.), The Sage Handbook of Educational Leadership: Advances in theory, research, and practice (pp. $47-67)$. Thousand Oaks, CA: Sage.

Spreen, C.A., \& Vally, S. (2006). Education rights, education policies and inequity in South Africa. International Journal of Educational Development, 26, $352-362$.

Starratt, R.J., (2004). Ethical Leadership, San Francisco, CA: Jossey-Bass.

Stevenson, H.P., (2007). A case study in leading schools for social justice: when morals and markets collide. Journal of Educational Administration, 45(6), 769 - 781 .

Swanepoel, C. (2008). The perceptions of teachers and school principals of each other's disposition towards teacher involvement in school reform. South African Journal of Education, 28, $39-51$.

Theoharis, G. (2007). Social justice educational leaders and resistance: Towards a theory of social justice leadership. Educational Administration Quarterly, 43(2), 221 - 258.

Theoharis, G. (2009). The school leaders our children deserve: Seven keys to equity, social justice and school reform. New York: Teachers' College Press.

Theoharis, G. (2010). Disrupting injustice: Principals narrate the strategies they use to improve their schools and advance social justice. Teachers' College Record, 112(1), $331-373$.

Theoharis, G., \& Frattura, E. (2008). Leading from the centre: Social justice leadership in the District Office. Paper presented at the UCEA Conference, Orlando, Florida, October 2008. 